\title{
A Grid Connected Modular Multilevel Converter for Photovoltaic Energy Conversion
}

\author{
Rachananjali Kunamneni ${ }^{*}$, Srinu Naik Ramavathu ${ }^{2}$ \\ ${ }^{1}$ Dept of EEE, Vignan's Foundation for Science, Technology \& Research, Vadlamudi 522213, AP, India \\ ${ }^{2}$ Dept of EE, AU College of Engineering (A), Visakhapatnam 530003, AP, India
}

Corresponding Author Email: rs_eee@ vignan.ac.in

https://doi.org/10.18280/mmep.060408

Received: 16 March 2019

Accepted: 29 August 2019

\section{Keywords:}

modular multilevel converter, photo voltaic, total harmonic distortion

\begin{abstract}
To capture the energy available in the solar radiations, modular multilevel converter has been proposed along with the photovoltaic module. The drawback with the solar energy is its instability and dependence of output energy. To overcome the drawback power converters have been introduced which increases the stability of the system. In this paper Modular Multilevel Converter (MMC) have been proposed due to its several features. The simulation is carried out and results are presented.
\end{abstract}

\section{INTRODUCTION}

Current scenario requires energy to perform any action. All the countries to be in the race of best countries are in need of huge energy, to meet their requirements they are increasing the generation by conventional sources of energy which is affecting the environment a lot. India is termed as the third largest producer and fourth largest consumer in the world. Its demand has increased more than 100 folds. In order to meet the demand and protect the environment many of the researchers are working to capture energy from renewable sources. Some of the renewable sources in demand are solar, wind, hydro and many more. Of the available renewable sources, the most widely preferred is solar energy. Due to the geographical conditions India has been gifted with sufficient solar energy apart from several indirect forms such as hydro power, ocean energy, wind energy, bio-energy etc. International Energy Agency's (IEA) has estimated that the renewable energy generation will grow at the rate of $7.8 \%$ and with the latest technological advancements the energy can be generated from renewable sources in an economic way. In order to extract the energy from solar radiations, photo voltaic modules are placed [1-3]. Photo voltaic module is an assembly of solar cells. One of the reasons to prefer solar energy is the reduction in cost and increase in efficiency of photo voltaic cells. Apart from the manufacturing advantages more support is being given by the government to install photovoltaic modules [4]. This paper proposes the integration of photo voltaic module to modular multilevel converter. The system proposed for the conversion of energy and integration to grid is shown in Figure 1.

The single stage conversion is efficient, less costly and less complex due to a smaller number of power conversion stages. The inverter is being utilized for conversion of DC to AC. Depending on the grid specifications the inverters are connected directly to grid or via transformer. Substantial research is going on to increase the efficiency of the conversion by employing advanced converters one of them being Modular Multilevel Converter (MMC) [5, 6-10]. The modular multilevel converter is one of the multilevel converters which received attention in recent times due to its modular structure and using the sub modules for fault redundant operation [6, 8-12]. The proposed converter is already in usage for high voltage dc transmission lines. This paper presents PV integration to grid using MMC. The dc-link is formed with series connection of half-bridge sub-modules. PV-panel is connected across the capacitor of the sub-module. The paper is organized in five sections. Section-1 starts with introduction and literature review with respect to the proposed area. Section 2 introduces about the photovoltaic system. The proposed converter configuration is presented in section-3. The control schemes are presented in section-4. The complete system is simulated in MATLAB and the results are given in section-5. Finally, section-6 concludes the work.

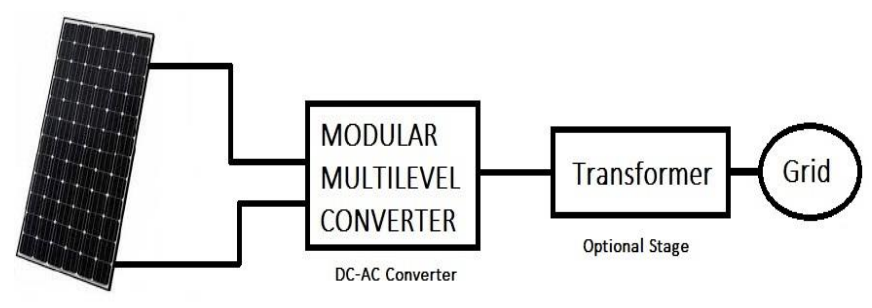

Figure 1. Block diagram of proposed system

\section{PHOTOVOLTAIC SYSTEM}

To extract the solar energy the interface used is photovoltaic cell. As the output obtained from a single photovoltaic cell is low so as to increase the output photovoltaic cells are connected in different connections. The transformation of light energy to electrical energy is known as photovoltaic effect. The converted energy is in the form of DC voltage 3. In literature PV cell is described as shown in Figure 2.

Current and Voltage generated by PV cell has a non-linear relation as shown in Figure 3 at a consistent temperature of $25^{\circ}$ C. Solar radiation controls the amount of current generated by PV cell which is shown in Figure 3 whereas temperature 
controls the voltage which is represented in Figure 4.

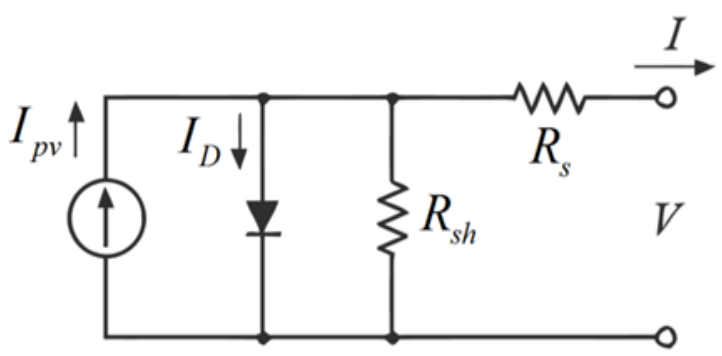

Figure 2. PV cell represented in single diode model

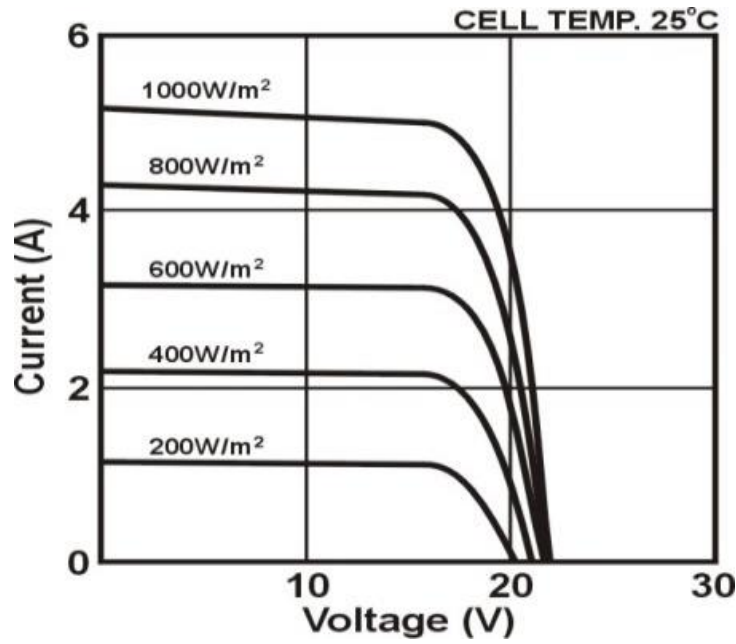

Figure 3. I-V characteristics of PV module for varying irradiance with constant temperature

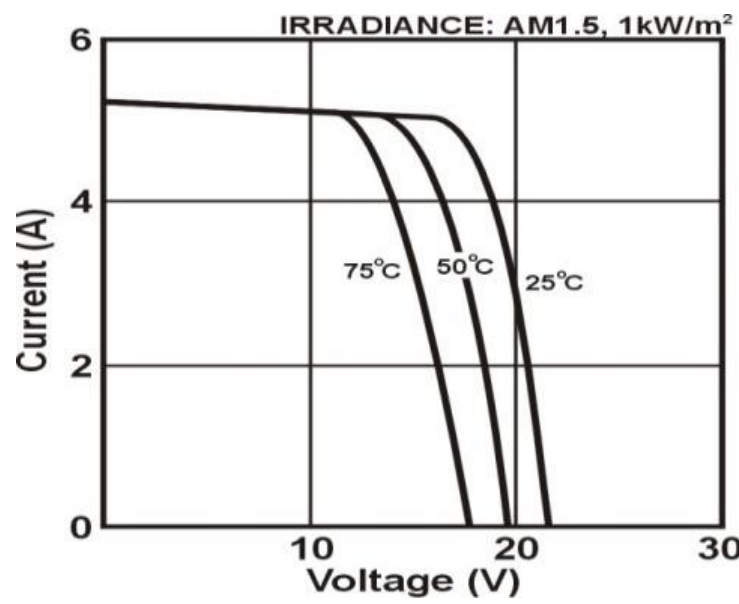

Figure 4. I-V characteristics of PV module for varying temperature at constant irradiance

\section{CONVERTER CONFIGURATION}

Power electronic converters play a vital role for the efficient conversion of renewable sources of energy. One section of converters employs midway DC link and another category directly converts fixed AC to variable AC without any midway DC link. Voltage source converters utilizes midway DC link. Depending on the output voltage, voltage source converters have been classified as two-level inverters and multilevel inverters. As multilevel inverters have better efficiency when compared to two level inverters they are preferred. Modular
Multilevel Converter is one of the topologies in multi cell converter family. It eliminates the need for isolated DC source and transformer. Modular Multilevel Converter is a cascade connection of cells or submodules to obtain the desired highquality multilevel output voltage waveform. The submodule is the building block and can be configured depending on the application. The various sub modules configurations available are half bridge, full bridge, flying capacitor, cascaded half bridge, double clamp [13-15]. The circuit configuration of 3 phase MMC is shown in Figure 5.

The sub modules can be evaluated in terms of rating, operation, control and design complexity. The simple construction of half bridge sub module results in selection of the particular sub module among other available sub modules. During normal operation only one switch will be "ON" state which reduces the losses and increases efficiency. But the output voltage cannot support the bipolar operation and fault blocking capability. The comparison of various submodules is represented in Table 1.

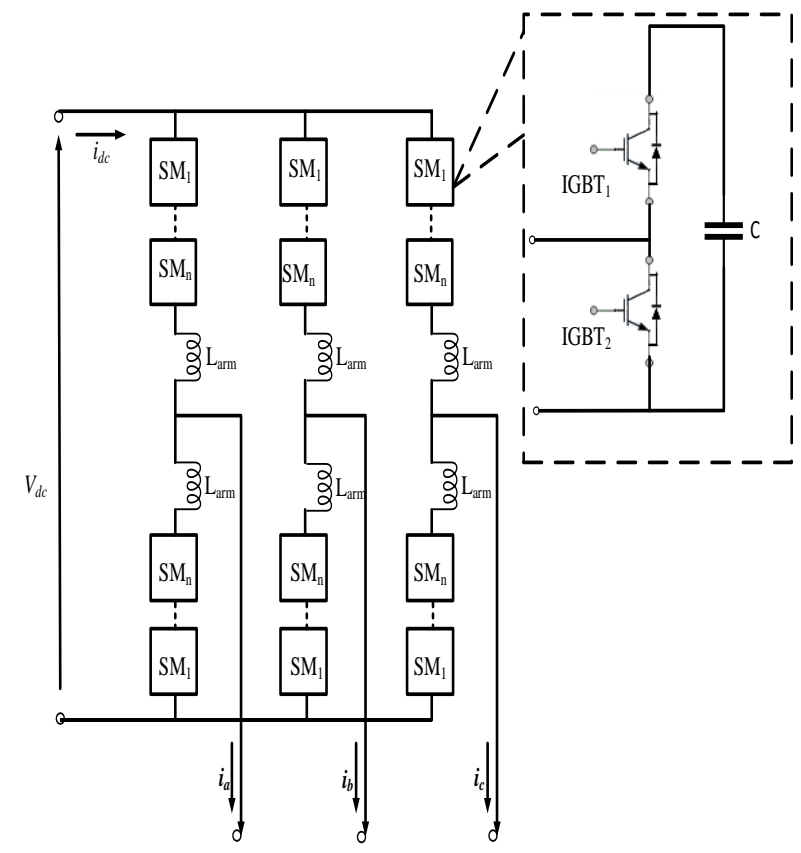

Figure 5. Circuit configuration of three phase MMC

The name itself suggests that the modular multilevel converter uses multiple half bridge sub modules with an identical construction in each arm to generate the multiple stepped waveform at the output. To explain the operation in detail four half bridge sub modules are considered and the connection is shown in Figure 6.

The submodule output terminals are connected in series to form an arm voltage. The switching states, the output voltage of each submodule and arm voltage can be illustrated and is represented in Table 2. On utilizing four sub modules the arm voltage generates five voltage levels as $0, V_{c}, 2 V_{c}, 3 V_{c}, 4 V_{c}$. The voltage levels can be generated depending on the switching states. As for to generate $4 \mathrm{~V}_{\mathrm{c}}$, the 4 switches need to be turned on whereas for $3 \mathrm{~V}_{\mathrm{c}}, 3$ switches need to be turned on. The intermediate voltage levels can be generated by utilizing multiple switching combinations. The arm voltage is the summation of sub module output voltage. To obtain the multilevel voltage waveform across the AC system accordingly the submodules in the upper and lower arms are controlled. 
Table 1. Comparison of various sub modules

\begin{tabular}{|c|c|c|c|c|c|}
\hline Performance Index & Half Bridge & Full Bridge & Flying Capacitor & Cascaded Half Bridge & Double Clamp \\
\hline No of output voltage levels & 2 & 3 & 3 & 3 & 4 \\
\hline Max blocking voltage & $\mathrm{V}_{\mathrm{c}}$ & $\mathrm{V}_{\mathrm{c}}$ & $2 \mathrm{~V}_{\mathrm{c}}$ & $2 \mathrm{~V}_{\mathrm{c}}$ & $2 \mathrm{~V}_{\mathrm{c}}$ \\
\hline Power losses & Low & Moderate & Moderate & Moderate & High \\
\hline Bipolar operation & No & Yes & No & No & Yes \\
\hline Design complexity & Low & Low & High & Low & High \\
\hline Control Complexity & Low & Low & High & Low & Low \\
\hline DC Fault blocking & No & Yes & No & No & Yes \\
\hline
\end{tabular}

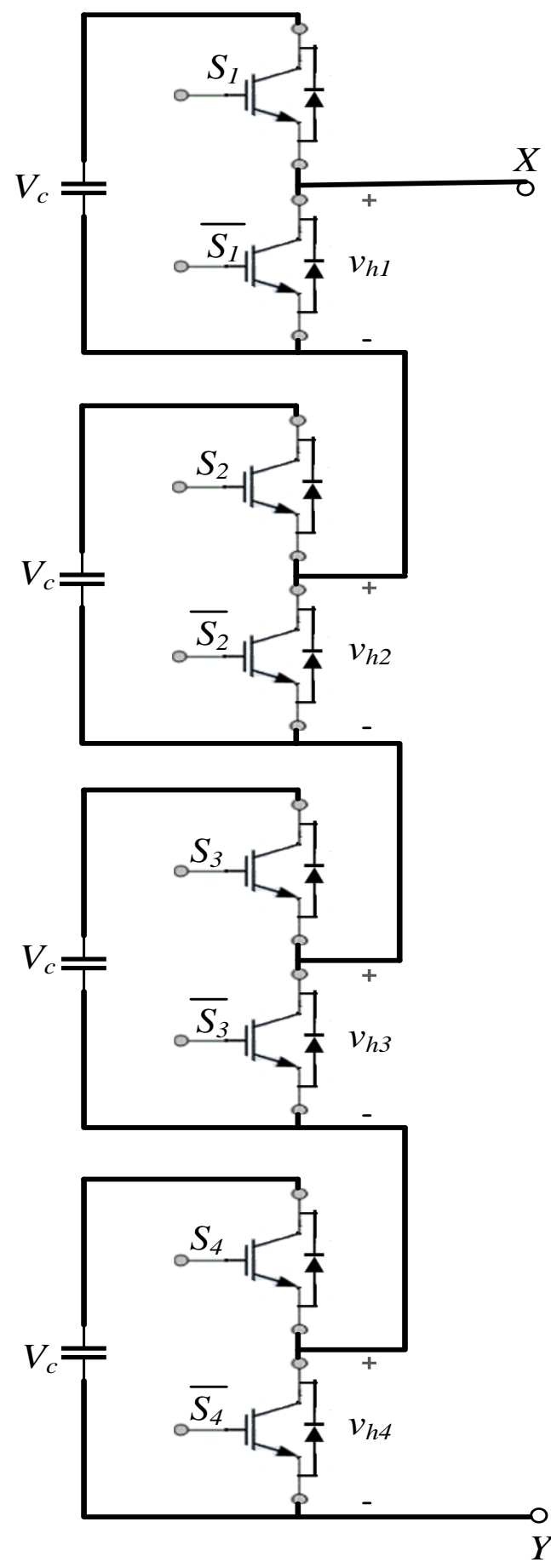

Figure 6. One arm of MMC containing 4 submodules

In this paper half bridge sub module has been implemented This submodule is commonly referred to as chopper cell. The switches are being operated in a complementary manner. Usually the switches used are IGBT and it has a diode connected in anti-parallel with the IGBT. Figure 7 shows the circuit diagram of half bridge submodule.
Table 2. Voltage level and switching state

\begin{tabular}{|cccccccccc|}
\hline$S_{1}$ & $S_{2}$ & $S_{3}$ & $S_{4}$ & $V_{h 1}$ & $V_{h 2}$ & $V_{h 3}$ & $V_{h 4}$ & $V_{x y}$ & $\begin{array}{c}\text { Voltage } \\
\text { Level }\end{array}$ \\
\hline 0 & 0 & 0 & 0 & 0 & 0 & 0 & 0 & 0 & 0 \\
\hline 1 & 0 & 0 & 0 & $V_{c}$ & 0 & 0 & 0 & $V_{c}$ & \\
0 & 1 & 0 & 0 & 0 & $V_{c}$ & 0 & 0 & $V_{c}$ & \\
0 & 0 & 1 & 0 & 0 & 0 & $V_{c}$ & 0 & $V_{c}$ & 1 \\
0 & 0 & 0 & 1 & 0 & 0 & 0 & $V_{c}$ & $V_{c}$ & \\
\hline 1 & 1 & 0 & 0 & $V_{c}$ & $V_{c}$ & 0 & 0 & $2 V_{c}$ & \\
1 & 0 & 1 & 0 & $V_{c}$ & 0 & $V_{c}$ & 0 & $2 V_{c}$ & \\
1 & 0 & 0 & 1 & $V_{c}$ & 0 & 0 & $V_{c}$ & $2 V_{c}$ & \\
0 & 1 & 1 & 0 & 0 & $V_{c}$ & $V_{c}$ & 0 & $2 V_{c}$ & 2 \\
0 & 1 & 0 & 1 & 0 & $V_{c}$ & 0 & $V_{c}$ & $2 V_{c}$ & \\
0 & 0 & 1 & 1 & 0 & 0 & $V_{c}$ & $V_{c}$ & $2 V_{c}$ & \\
\hline 1 & 1 & 1 & 0 & $V_{c}$ & $V_{c}$ & $V_{c}$ & 0 & $3 V_{c}$ & \\
1 & 1 & 0 & 1 & $V_{c}$ & $V_{c}$ & 0 & $V_{c}$ & $3 V_{c}$ & \\
1 & 0 & 1 & 1 & $V_{c}$ & 0 & $V_{c}$ & $V_{c}$ & $3 V_{c}$ & 3 \\
0 & 1 & 1 & 1 & 0 & $V_{c}$ & $V_{c}$ & $V_{c}$ & $3 V_{c}$ & \\
\hline 1 & 1 & 1 & 1 & $V_{c}$ & $V_{c}$ & $V_{c}$ & $V_{c}$ & $4 V_{c}$ & 4 \\
\hline
\end{tabular}

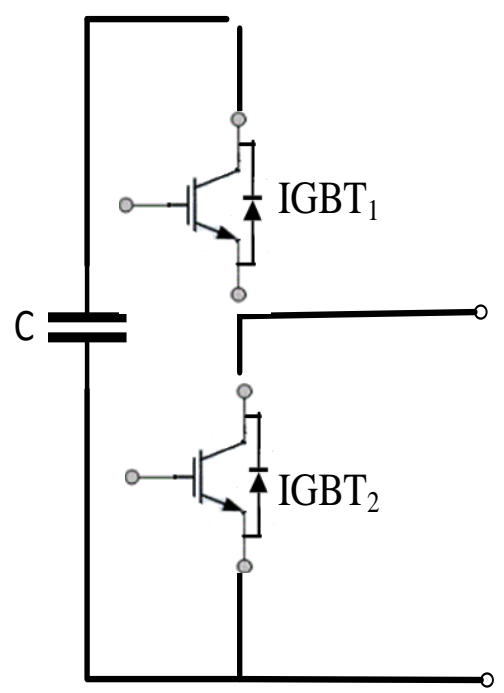

Figure 7. Circuit diagram of half bridge submodule

The switching states of half bridge submodule can be explained in Table 3 .

Table 3. Output voltage corresponding to switching state of IGBT1

\begin{tabular}{|c|c|}
\hline IGBT1 & AC Output voltage \\
\hline 1 & $\mathrm{Vc}$ \\
\hline 0 & 0 \\
\hline
\end{tabular}


The output voltage will be equal to capacitor voltage when IGBT1 is "ON" and when IGBT1 is "OFF" the output voltage will be zero. Hence the output voltage will be square waveform as shown in Figure 8 .

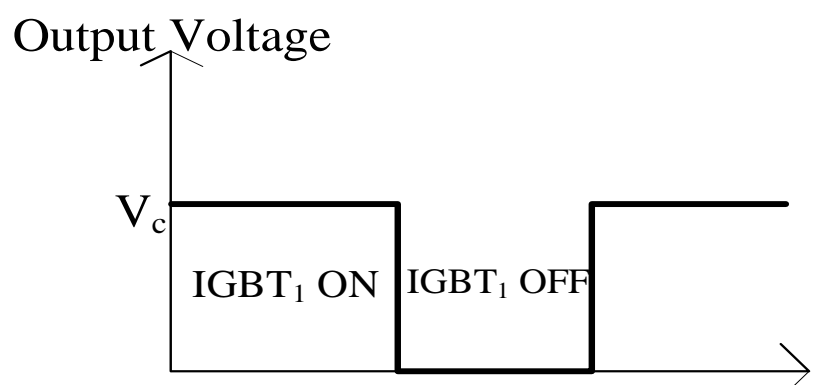

Figure 8. Output voltage of half bridge submodule

\section{CONTROL SCHEMES}

The control of MMC involves many challenges and some of the control objectives are output current control, capacitor voltage control and circulating current control. The circulating current control is secondary objective and due to the inclusion of arm inductance circulating current can be controlled. The primary and secondary objectives can be met by classical and predictive control techniques. The operating principle of MMC requires a differential voltage between the DC side and the overall DC component of the output voltage. Due to which circulating current is produced which controls the power transfer between the converter. Independent of the control strategy the average power transfer through each cell has to be zero. The different control strategies are Output active and reactive power control, DC bus voltage control, circulating current control, overall submodules capacitor voltage control, submodules capacitor voltage balancing. Pulse Width Modulation (PWM) techniques are widely used for controlling the AC output voltage of converter. The desired AC output voltage is obtained by varying the switching states of the sub modules utilized in the MMC. PWM techniques came into picture in order to reduce the harmonic distortion and for the desired frequency the magnitude of the output voltage can be increased. The gating signals for the switching devices are generated on comparison of modulation signal and carrier signal. They are widely preferred due to its simple implementation and no of voltage levels can be easily increased. MMC employed with $\mathrm{N}$ submodules per arm requires $\mathrm{N}$ carrier signal of triangle in nature. Usually the signals applied to lower and upper arm are displaced with an interleave angle $\left(\phi_{\mathrm{ci}}\right)$. The interleave angle can be calculated as

$$
\phi_{c i}=\frac{360^{\circ}}{2 N}
$$

On using the interleave angle the modular multilevel converter can generate an output with $2 \mathrm{~N}+1$ voltage level. If for the upper and lower arms similar triangular signals are used as carrier it would generate $\mathrm{N}+1$ voltage level. The reduction in voltage levels increase the content of harmonics in the output waveform which is not desirable.

\section{PROPOSED SYSTEM}

The proposed MMC for photo voltaic system is simulated with MATLAB environment. The proposed system parameters are shown in Table 4. Figure 9 and Figure 10 represents the $\mathrm{I} V$ and $\mathrm{P} \mathrm{V}$ characteristics of the PV cell designed in MATLAB environment. Figure 11 shows the half bridge submodule implemented in MATLAB. Figure 12 represents the proposed in MATLAB environment. Figure 13 shows the output voltage of MMC. Figure 14 represents the THD analysis of output voltage and Figure 15 shows the output current obtained from MMC.

Table 4. Parameters of proposed system

\begin{tabular}{|c|c|}
\hline Item & Value \\
\hline PV array rated power & $1.356 \mathrm{KW}$ \\
\hline Solar radiation & $1000 \mathrm{~W} / \mathrm{m}^{2}$ \\
\hline Cell temperature & $25^{\circ} \mathrm{C}$ \\
\hline System frequency & $50 \mathrm{~Hz}$ \\
\hline Grid voltage & 230 \\
\hline
\end{tabular}

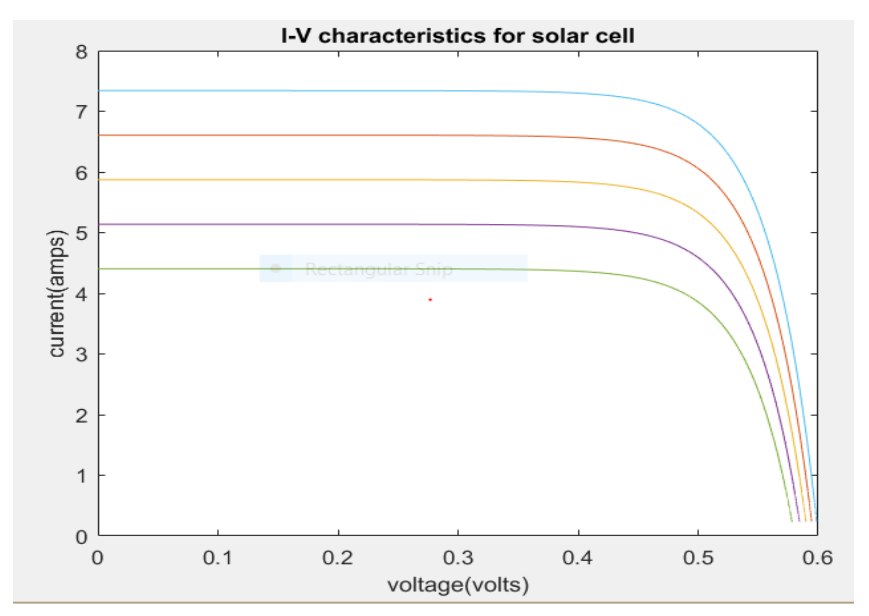

Figure 9. I V Characteristics of PV cell

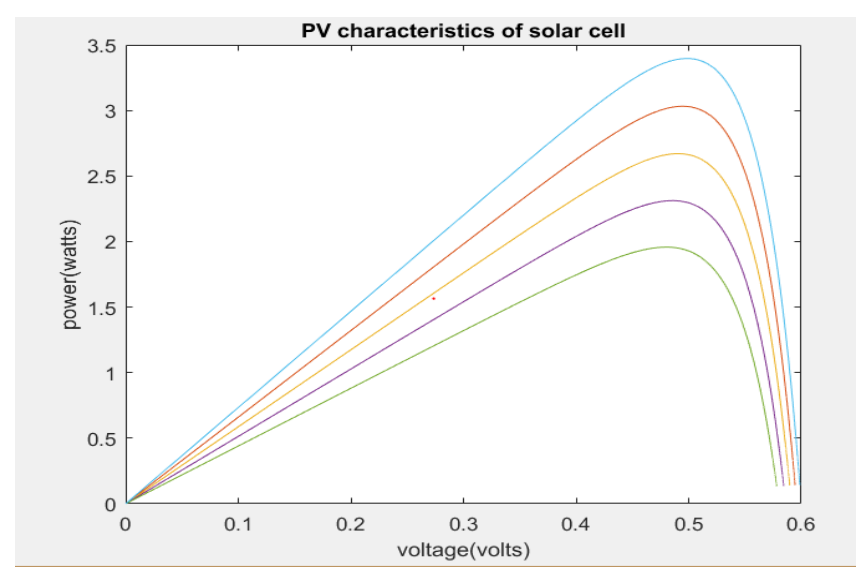

Figure 10. P V Characteristics of PV cell 


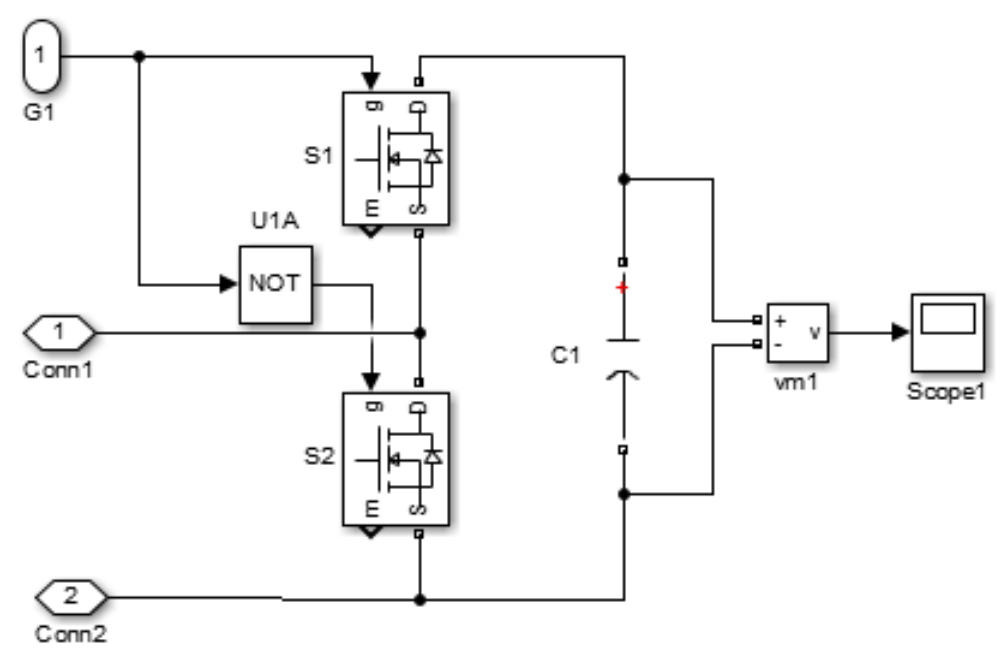

Figure 11. Half bridge submodule implemented in MATLAB
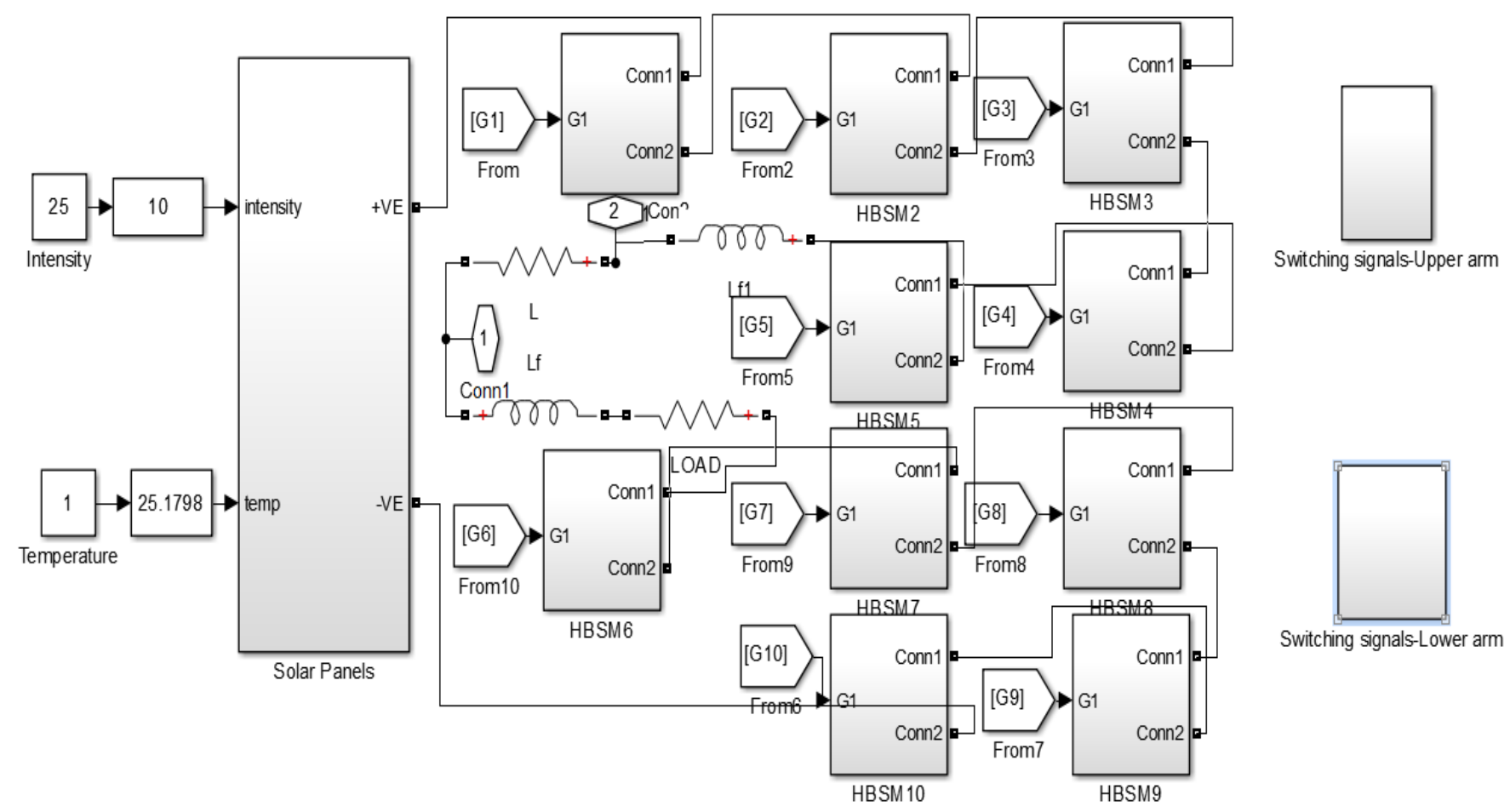

Figure 12. Simulink model of MMC with solar panel

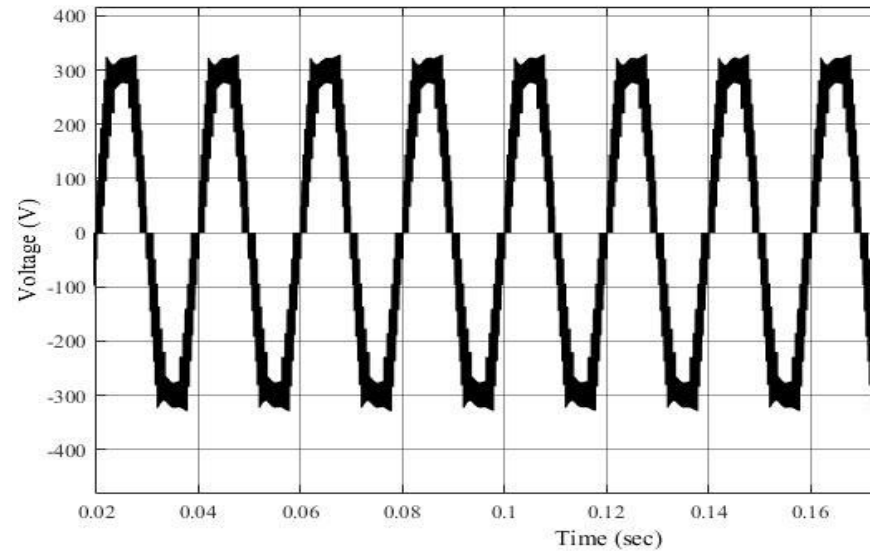

Figure 13. Output voltage of MMC

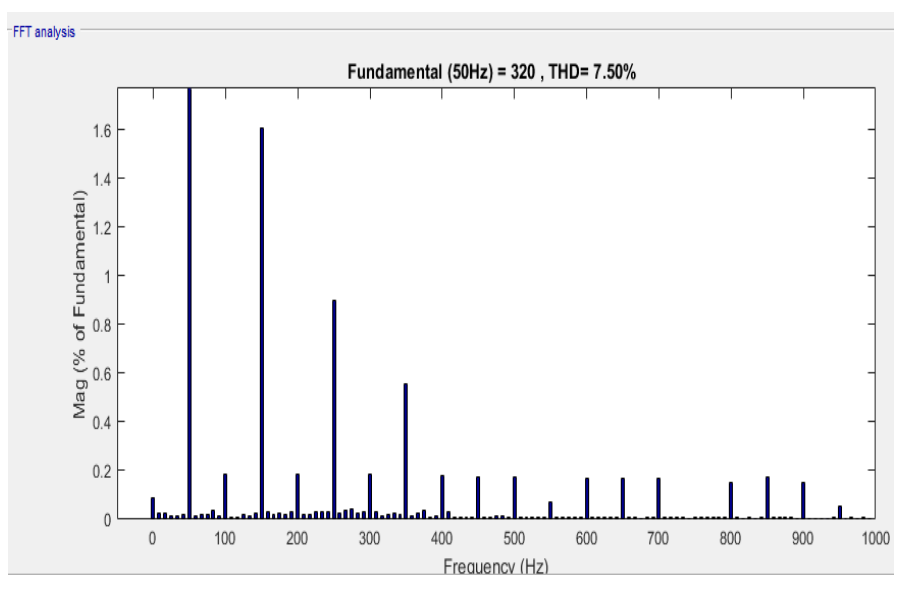

Figure 14. THD analysis of the output voltage 


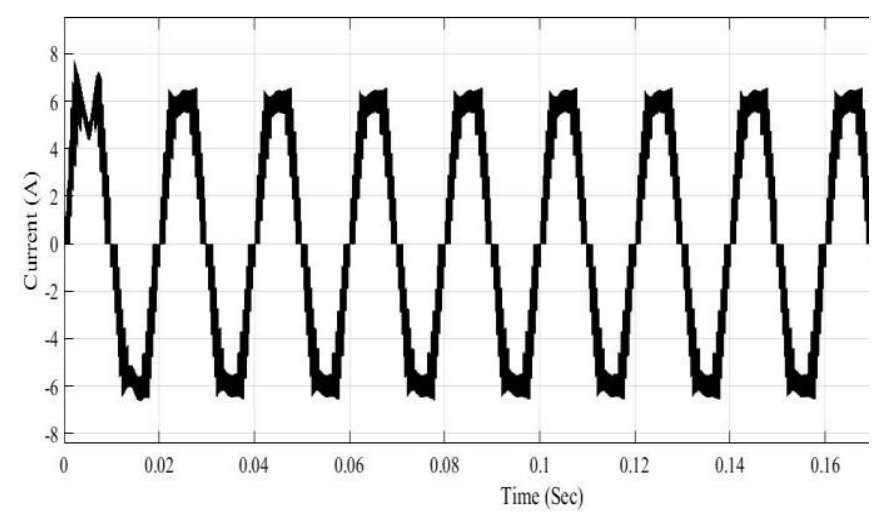

Figure 15. Output current obtained from MMC

\section{CONCLUSION}

In this paper the energy is extracted from sun radiations with the help of photovoltaic cells. The energy is available in the form of DC voltage and it is converted to AC voltage with Modular Multilevel Converter (MMC). The proposed system has been discussed. Harmonic analysis of the output voltage has been discussed and observed that on increasing the no of levels of the output voltage THD can be considerably decreased. THD may decrease with increase in levels of MMC without increasing the switching frequency so as to limit the switching losses. The proposed system can be further extended for wind energy conversion system. Apart from solar and wind it can be implemented for hybrid combination of the two.

\section{ACKNOWLEDGMENT}

This publication is an outcome of the $R \& D$ work undertaken project under the Visvesvaraya $\mathrm{PhD}$ Scheme of Ministry of Electronics \& Information Technology, Government of India, being implemented by Digital India Corporation.

\section{REFERENCES}

[1] Rajasekar, S., Gupta, R. (2012). Solar photovoltaic power conversion using modular multilevel converter. 2012 Students Conference on Engineering and Systems, Allahabad, Uttar Pradesh, India, pp. 1-6. https://doi.org/10.1109/SCES.2012.6199035

[2] Ramya, G., Ramaprabha, R. (2015). Switching loss and THD analysis of modular multilevel converter with different switching frequency. 2015 IEEE 11th International Conference on Power Electronics and Drive Systems, Sydney, NSW, Australia, pp. 336-340. https://doi.org/10.1109/peds.2015.7203504

[3] Basu, T.S., Maiti, S., Chakraborty, C. (2016). A hybrid modular multilevel converter for solar power integration. 2016 IEEE 7th Power India International Conference (PIICON), Bikaner, India, pp 1-6. 10.1109/POWERI.2016.8077444
[4] Rachananjali K., Srinu Naik R, "Design of Modular Multilevel Converter for micro grid inked photovoltaic system", IEEE $8^{\text {th }}$ India International Conference on Power Electronics, pp 1-6, 2018. https://doi.org/10.1109/IICPE.2018.8709606

[5] Kauro, S., Leon, J.I., Vinnikov, D., Franquelo, L.D. (2015). Grid connected photovoltaic system- An overview of recent research and emerging PV converter topologies. IEEE Ind. Electron. Magazine, 9(1): 47-61. https://doi.org/10.1109/MIE.2014.2376976

[6] Martinez-Rodrigo, F., Ramirez, D., Rey-Boue, A.B., De Pablo, S., Herrero-de Lucas, L.C. (2017). Modular multilevel converters: Control and applications. Energies 10(11): 1709. https://doi.org/10.3390/en10111709

[7] Ganesh, G., Vijay Kumar, G., Vijay Babu, A.R., G., Srinivasa Rao, Y.R. (2015). Performance analysis and MPPT control of a standalone hybrid power generation system. Journal of Electrical Engineering, 15(1): 334343.

[8] Debnath, S., Qin, J.C., Bahrani, B., Seedifard, M., Barbosa, P. (2015). Operation, control, and applications of the modular multilevel converter: A review. IEEE Transaction on Power Electronics, 30(1):37-53. https://doi.org/10.1109/TPEL.2014.2309937

[9] Edpuganti, A., Rathore, A.K. (2016). Optimal pulsewidth modulation of medium-voltage modular multilevel converter. 2015 IEEE Industry Applications Society Annual Meeting, 52(4): 3435-3442. https://doi.org/10.1109/IAS.2015.7356824

[10] Perez, M.A., Bernet, S., Rodriguez, J., Kouro, S., Lizana, R. (2015). Circuit topologies, modeling, control schemes and applications of modular multilevel converters. IEEE Transactions on Power Electronics, 30(1): 4-17. https://doi.org/10.1109/TPEL.2014.2310127

[11] Karasani, R.R., Borghate, V.B., Meshram, P.M., Suryawanshi, H.M., Sabyasachi, S. (2017). A threephase hybrid cascaded modular multilevel inverter for renewable energy environment. IEEE Transaction on Power Electronics, 32(2): 1070-1087. https://doi.org/10.1109/TPEL.2016.2542519

[12] Nademi, H., Elahidoost, A., Norum, L.E. (2016). Comparative analysis of different MPPT schemes for photovoltaic integration of modular multilevel converter. In IEEE 17th Workshop on Control and Modeling for Power Electronics (COMPEL), Trondheim, Norway. https://doi.org/10.1109/COMPEL.2016.7556743

[13] Rachananjali, K., Srinu Naik, R., Suguna, K. (2017). Implementation of modular multilevel converter. Journal of Advanced Research in Dynamical and Control Systems, 9(5): 251-258.

[14] Alexander, A., Thathan, M. (2015). Modelling and analysis of modular multilevel converter for solar photovoltaic applications to improve power quality. IET Renewable Power Generation, 9(1): 78-88. https://doi.org/10.1049/iet-rpg.2013.0365

[15] Hagiwara, M., Akagi, H. (2009). Control and experiment of pulse width modulation modular multilevel converters. IEEE Transaction on Power Electronics, 24(7): 17371746. https://doi.org/10.1109/TPEL.2009.2014236 